\title{
A study of spot urine protein: creatinine ratio as an alternative to 24 hours proteinuria for the diagnosis of pre-eclampsia
}

\author{
Ruma Sarkar $^{1}$, Shilpi Rawat ${ }^{2 *}$, Neela Rai Sharma ${ }^{1}$, Harish Chandra Tiwari ${ }^{1}$
}

\begin{abstract}
${ }^{1}$ Department of Obstetrics and Gynecology, BRD Medical College Gorakhpur, Uttar Pradesh, India
${ }^{2}$ Department of Obstetrics and Gynecology, MLN Medical College, Prayagraj, Uttar Pradesh, India
\end{abstract}

Received: 01 October 2019

Revised: 15 November 2019

Accepted: 19 November 2019

\author{
*Correspondence: \\ Dr. Shilpi Rawat, \\ E-mail: drshilpirawat08@gmail.com
}

Copyright: ( $)$ the author(s), publisher and licensee Medip Academy. This is an open-access article distributed under the terms of the Creative Commons Attribution Non-Commercial License, which permits unrestricted non-commercial use, distribution, and reproduction in any medium, provided the original work is properly cited.

\begin{abstract}
Background: Preeclampsia is defined as systolic blood pressure level of $140 \mathrm{mmHg}$ or higher or a diastolic blood pressure level of $90 \mathrm{mmHg}$ or higher that occurs after 20 weeks of gestation with proteinuria. Objective of this study was to study the role of spot urine protein: creatinine ratio as an alternative to 24 hours proteinuria for the diagnosis of pre-eclampsia

Methods: This is a prospective observational study conducted in the department of obstetrics and gynaecology, BRD Medical College Gorakhpur, since October 2016 to September 2017 included 120 pregnant women with hypertension of gestational age more than 20 weeks. Ramdom urine sample of all the patient was taken before 12 noon after first voiding. For 24 hours urine sample patient was asked to collect all her urine she voids during 24 hours. The creatinine was estimated by the alkaline picrate method (Jaffe's Reaction) modified by the Bonsnes and Taussky, 1945. Creatinine in a protein free solution reacts with the alkaline picrate and produces red colour complex which is measured colorimeterically. Urinary protein was estimated in all the subjects by the Turbidimetric method. Urinary protein was precipitated by $3 \%$ sulphosalicylic acid and turbidity so produced was measured colorimetrically.

Results: Protein: creatinine ratio in a random urine sample is better than random urine protein detection by dipstick method in cases of emergency when there is no time for detection of 24 hours urine protein.

Conclusions: If cut-off level for urine protein: creatinine ratio in random urine sample is taken as 0.25 or more then sensitivity and specificity become same as 24 hours urine protein.
\end{abstract}

Keywords: Eclampsia, Fetal growth restriction, Gestational age, Pedal edema, Pre-eclampsia, Protein: creatinine ratio, 24 hours urine protein

\section{INTRODUCTION}

Preeclampsia is defined as systolic blood pressure level of $140 \mathrm{mmHg}$ or higher or a diastolic blood pressure level of $90 \mathrm{mmHg}$ or higher that occurs after 20 weeks of gestation with proteinuria. Preeclampsia is an important cause of maternal morbidity and mortality as well as a significant contributor to increased perinatal morbidity and mortality rates in India, $12 \%$ of all maternal deaths worldwide are due to hypertensive disorders of pregnancy. Proteinuria is defined as presence of $300 \mathrm{mg}$ or more protein in a 24 -hour urine specimen. ${ }^{1}$

There are many different causes for the condition. It appears likely that there are substances from the placenta that can cause endothelial dysfunction in the maternal blood vessels of susceptible women. While blood pressure elevation is the most visible sign of the disease. 
It involves generalised damage to the maternal endothelium, kidneys and liver with the release of vasoconstrictive f-actors being a consequence of the original damage.

The pre-eclampsia syndrome is thought in many cases to be caused by a shallowly implanted placenta which becomes hypoxic, leading to an immune reaction characterized by secretion of unregulated inflammatory mediators from the placenta, and acting on the vascular endothelium

\section{Diagnosis}

Pre-eclampsia is well diagnosed when a pregnant woman develops

Blood pressure $>140$ systolic and/or $>90$ diastolic (two separate readings taken at least four hours apart) and 0.3 grams or more of protein in a 24-hour urine sample (proteinuria) or $\geq 1$ persistent dipstick.

\section{Criteria for diagnosis of severe pre-eclampsia}

- Systolic blood pressure of $160 \mathrm{mmHg}$ or higher or diastolic $110 \mathrm{mmHg}$ or higher on two occasions at least 4 hours apart while the patient is in bed.

- Proteinuria of 5 gram or higher in 24 hours urine specimen or $3+$ or greater on two random urine samples collected at least 4 hours apart

- Oliguria of less than $500 \mathrm{ml}$ in 24 hours

- Cerebral or visual disturbances

- Pulmonary edema or cyanosis

- Epigastric or right upper quadrant pain

- Impaired liver function

- Thrombocytopenia

- Fetal growth restriction. $^{2}$

Swelling or edema (especially in the hands and face) was originally considered an important sign for a diagnosis of pre-eclampsia, but in current medical practice only hypertension and proteinuria are necessary for a diagnosis. Pitting edema (unusual swelling, particularly of the hands, feet, or face, notable by leaving an indentation when pressed on) can be significant and should be reported to a health care provider. ${ }^{3}$

Urine collection over 24 hours is considered the traditional Parameter for quantification of proteinuria in pregnancy. As 24 hours urine collection is difficult to patient so we have alternative method for quantitative evaluation of proteinuria is the measurement of protein: creatinine ratio in a spot urine sample, which provides a more convenient and rapid method to assess protein excretion. ${ }^{4}$

The dipstick is inexpensive, easy to use, and provides a rapid result but has been shown to have low sensitivity and specificity for urinary protein excretion over 24 hours.

Recently, the urine protein-creatinine ratio has been considered important for predicting proteinuria in pregnant patients. It compares the spot urine protein excretion to the spot urine creatinine excretion, thereby normalizing protein excretion to the glomerular filtration rate. Thus, the urine protein-creatinine ratio is not subject to variation due to hydration status. In pregnant women, the urine protein-creatinine ratio and the 24 hours urine are highly correlated. We carried out a systematic review to assess the diagnostic value of protein: creatinine ratio in a single voided urine sample compared with 24 hours urinary collection for the detection of significant proteinuria in hypertensive pregnant women attending the antenatal clinic or admitted in the antenatal ward. ${ }^{5}$

Objective of this study was to study the role of spot urine protein: creatinine as an alternative to 24 hours proteinuria for the diagnosis of pre-eclampsia.

\section{METHODS}

This study was conducted in the department of obstetrics and gynaecology, BRD Medical College Gorakhpur, from October 2016 to September 2017 includes cases pregnancy with hypertension.

\section{Inclusion criteria}

- Study population consisted of admitted antenatal cases of gestational age $>20$ weeks with raised blood pressure.

\section{Exclusion criteria}

- Women with known kidney disease, Bacteriuria, Bed rest longer than 24 hours, Gestational diabetes mellitus, women who delivered their babies during the urine collection, known patients on immunotherapy, immune compromised individuals, multiple pregnancy are excluded.

The 24 hours proteinuria and spot urine protein creatinine ratio will be recorded.

\section{Statistical analysis}

Student's t-test will be applied using SPSS software.

\section{RESULTS}

In the mentioned (Table 1), out of total 120 patients 96 were detected as pre-eclampsia and had significant proteinuria. Among them 84 had proteinuria in the range of $0.3-1.5$. Only 4 had proteinuria $0.3 \mathrm{gm} / 24$ hours and 8 had proteinuria in the range of 1.6-2 $\mathrm{gm} / 24$ hours. 
Table 1: Distribution of patients according to 24 hours urine protein.

\begin{tabular}{|lll|}
\hline $\begin{array}{l}\text { 24 hours urine } \\
\text { protein }(\mathrm{gm} / \mathbf{2 4} \text { hours })\end{array}$ & $\begin{array}{l}\text { Number of } \\
\text { cases }\end{array}$ & $\begin{array}{l}\text { Percentage } \\
(\%)\end{array}$ \\
\hline$<0.3$ & 24 & $20 \%$ \\
\hline 0.3 & 4 & $3.33 \%$ \\
\hline $0.3-1.5$ & 84 & $70 \%$ \\
\hline $1.6-2$ & 8 & $6.66 \%$ \\
\hline & Total = 120 & $\mathbf{1 0 0 \%}$ \\
\hline
\end{tabular}

Table 2: Distribution of patients according to protein: creatinine ratio in spot urine.

\begin{tabular}{|lll|}
\hline $\begin{array}{l}\text { Protein : creatinine ratio } \\
\text { in spot urine sample }\end{array}$ & $\begin{array}{l}\text { Number } \\
\text { of cases }\end{array}$ & $\begin{array}{l}\text { Percentage } \\
(\%)\end{array}$ \\
\hline $0.12-0.2$ & 24 & $20 \%$ \\
\hline 0.25 & 4 & $3.33 \%$ \\
\hline $0.25-0.43$ & 84 & $70 \%$ \\
\hline $0.52-0.63$ & 8 & $6.66 \%$ \\
\hline & Total = 120 & $\mathbf{1 0 0 \%}$ \\
\hline
\end{tabular}

Table 2 shows, among the 120 patients in the study population, 24 patients had a protein: creatinine ratio in the range of $0.12-0.2,84$ had a ratio between $0.25-0.43$, while only 8 had a ratio in the range of $0.52-0.63$.

Correlation between protein: creatinine ratio in spot sample and 24 hours urinary protein excretion in $\mathrm{gm} / 24$ hours in pre eclamptic patients. After applying student " $\mathrm{t}$ " test the linear correlation coefficient between the protein: creatinine ratio and 24 hours urine protein excretion was found highly significant $(\mathrm{r}=0.98, \mathrm{p}=<0.0001)$ ( $\mathrm{t}$ at $4 \mathrm{df}$ $=9.877084)$ (Figure 1).
Table 3: Distribution of patients showing correlation between $\mathrm{P} / \mathrm{C}$ ratio and 24 hours urine protein excretion.

\begin{tabular}{|lll|}
\hline $\begin{array}{l}\text { Number of } \\
\text { cases }\end{array}$ & $\begin{array}{l}\mathbf{2 4} \text { hours proteinuria } \\
(\mathrm{gm} / \mathbf{2 4} \text { hours })\end{array}$ & $\begin{array}{l}\text { Spot } \mathrm{P} / \mathrm{C} \\
\text { ratio }\end{array}$ \\
\hline 24 & $<0.3$ & $0.12-0.2$ \\
\hline 4 & 0.3 & 0.25 \\
\hline 84 & $0.3-1.5$ & $0.25-0.43$ \\
\hline 8 & $1.6-2$ & $1.6-2$ \\
\hline
\end{tabular}

The linear correlation coefficient between the protein: creatinine ratio and 24 hours urine protein excretion were found highly significant $(\mathrm{r}=0.98, \mathrm{p}<0.0001)$ (" $\mathrm{t}$ " at $4 \mathrm{df}$ $=9.877084$ ).

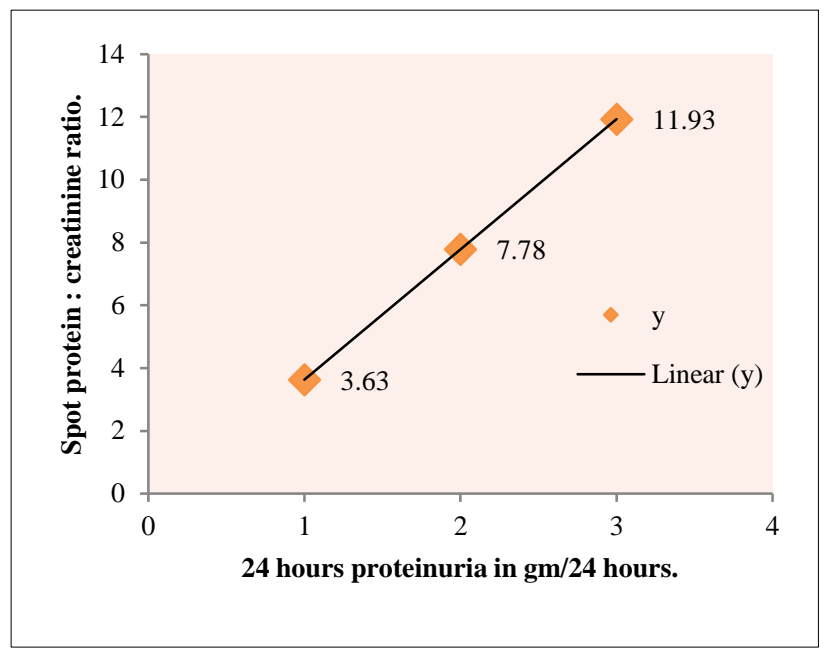

Figure 1: XY data: correlation of data file.

Table 4: Comparison of 24 hours urine protein to protein: creatinine ratio in a single voided urine sample $(\mathrm{n}=\mathbf{1 2 0})$.

\begin{tabular}{|lllll|}
\hline Type & $\begin{array}{l}\text { Number of } \\
\text { cases }\end{array}$ & $\begin{array}{l}\mathbf{2 4} \text { hours proteinuria gm/24 } \\
\text { hours }(\mathbf{0 . 3})\end{array}$ & $\begin{array}{l}\text { Number of } \\
\text { cases }\end{array}$ & $\begin{array}{l}\text { Spot P/C ratio } \\
(\geq 0.3)\end{array}$ \\
\hline Preeclampsia & 96 & $\geq 0.3$ & 76 & $\geq 0.3$ \\
\hline Pregnancy with hypertension & 24 & $<0.3$ & 44 & $<0.3$ \\
\hline & Total $=\mathbf{1 2 0}$ & & Total = 120 & \\
\hline
\end{tabular}

Table 4 shows that out of 120 pregnant women with hypertension, 96 had a 24 hours urine protein excretion $\geq 0.3 \mathrm{gm} / 24$ hours. Among them protein: creatinine ratio was positive in (cut off value- 0.3) 76 patients, which were true positive subjects in the study while the 20 subjects had a negative protein: creatinine ratio were the false negative subjects. 44 patients had a protein: creatinine ratio $<0.3$. Out of them 24 hours urine protein excretion $<0.3 \mathrm{gm} / 24$ hours in 24 patients who were true negative subjects and 20 had a positive protein: creatinine ratio who were the false positive study subjects. So, protein: creatinine ratio had a sensitivity of $79 \%$ and specificity of $54 \%$. Thus, it can be said that protein: creatinine ratio is able to correctly identify 76 out of 96 patients with significant proteinuria when the comparison is made with the gold standard test that is 24 hours urine protein.

Table 5 shows that out of 120 pregnant patients with hypertension, 96 had a 24 hours urine protein excretion $\geq 0.3 \mathrm{gm} / 24$ hours, which is correlated with protein: creatinine ratio of $\geq 0.25$. So, if cut-off value of protein: creatinine ratio is 0.25 , diagnosed 96 patients out of 120 patients as pre-eclampsia and rest 24 were diagnosed as 
pregnancy with hypertension. So, if take cut off value for protein: creatinine ratio is taken in random urine sample 0.25 or more then sensitivity and specificity become same as 24 hours urine protein.

Table 5: Comparison of protein creatinine ratio in a single voided urine sample to 24 hours urine protein in study subjects $(n=120)$.

\begin{tabular}{|lll|}
\hline $\begin{array}{l}\text { Number } \\
\text { of cases }\end{array}$ & $\begin{array}{l}\text { 24 hours urine protein } \\
\text { in gm/24 hours }\end{array}$ & $\begin{array}{l}\text { Spot protein: } \\
\text { creatinine ratio }\end{array}$ \\
\hline 96 & $\geq 0.3$ & $\geq 0.25$ \\
\hline 24 & $<0.3$ & $<0.25$ \\
\hline
\end{tabular}

\section{DISCUSSION}

Out of the 120 patients included in the study 96 patients had proteinuria more than or equal to $0.3 \mathrm{gm} / 24$ hours. As shown in (Table 1) majority of patients had proteinuria in the range of $0.3-1.5 \mathrm{gm} /$ day. And it is evident from Table 2 that majority of patients had a P/C ratio in the range of $0.25-0.43$ and only 4 patients had a $\mathrm{P} / \mathrm{C}$ ratio of 0.25 . The mean urinary protein excretion in 24 hours urine collections was $0.8365 \pm 0.50 \mathrm{gm} / 24$ hours (range, 0.2-1.96 gm/24 hours). The mean $\mathrm{P} / \mathrm{C}$ ratio was $0.3226 \pm 0.10$ (range, 0.12-0.63).

Several investigators have explored other means of quantifying proteinuria in a shorter period. In this study a comparison of the protein: creatinine ratio with the standard 24 hours protein estimation using the various indices of validity was quite revealing. Sensitivity, specificity. Table 3 shows correlation of 24 hours urine protein and protein: creatinine ratio. The linear correlation coefficient between the protein: creatinine ratio and 24 hours urine protein excretion was found highly significant $(\mathrm{r}=0.98, \mathrm{p}<0.0001)$ (" $\mathrm{t}$ " at $4 \mathrm{df}=$ 9.877084), which is comparable to Shahbaazian N et al, study. ${ }^{6}$ They found the strong correlation between the spot $\mathrm{P} / \mathrm{C}$ ratio and 24 hours urine protein excretion $(\mathrm{r}=0.84, \mathrm{p}<0.001)$. The optimal spot $\mathrm{P} / \mathrm{C}$ ratio cut off point was 0.2 for $300 \mathrm{mg} / 24$ hours of protein excretion with sensitivity $91.2 \%$, specificity $87.8 \%$.

Table 4 shows out of 120 patients pregnancy with hypertension, 96 patients had a 24 hours urine protein excretion greater than or equal to $300 \mathrm{mg}$. Among 96 patients the $\mathrm{P} / \mathrm{C}$ ratio was positive (cut off value- 0.3 ) in 76 patients, which signifies that these were the true positive subjects in the study while the 20 study subjects who had a negative $\mathrm{P} / \mathrm{C}$ ratio were the false negative subjects. 44 cases of pregnancy with hypertension had $\mathrm{P} / \mathrm{C}$ ratio $<0.3$. Out of them 24 hours urine protein excretion $<300 \mathrm{mg}$ in 24 patients who were true negative study subjects and 20 had a positive $\mathrm{P} / \mathrm{C}$ ratio that is they were the false positive study subjects. So, P/C ratio had a sensitivity of $79 \%$ and specificity of $54 \%$. Thus, we can say that $\mathrm{P} / \mathrm{C}$ ratio is able to correctly identify 76 out of 96 patients with significant proteinuria when the comparison is made with the gold standard test that is 24 hours urine protein. In similar study done by Hossain et al, they found that urine $\mathrm{P} / \mathrm{C}$ ratio had a sensitivity of $91.67 \%$ and the specificity $80 \%$ and ( $p$ value is $<0.0000001$ ) for discriminating insignificant and significant proteinuria. $^{7}$ Based on the above findings they concluded that a random urine protein excretion predicts the amount of 24 hours urine protein excretion with high accuracy.

Table 5 shows it is clear that if cut off value is taken for urine $\mathrm{P} / \mathrm{C}$ ratio in random urine sample 0.25 or more then sensitivity and specificity become same as 24 hours urine protein. Similar study done by Majid S et al, among 551 pre-eclamptic patients and concludes that urine $\mathrm{P} / \mathrm{C}$ ratio has shown a high sensitivity, specificity and diagnostic accuracy (at a cut off value of >0.3). ${ }^{8}$ So it can be considered a reliable investigation among pre eclamptic patients. The spot urine $\mathrm{P} / \mathrm{C}$ ratio can provide excellent discrimination between patients with and without significant proteinuria. This test can be used for prompt clinical decision in spite of waiting for 24 hours urine collection. In a similar study done by Aggarwal et al, in 120 pre eclamptic women, the mean age was 26 years and mean gestational age was 32 weeks. ${ }^{9}$ They reported a significant association between the two tests with a correlation coefficient of $r=0.596(p<0.01)$ and the sensitivity and specificity of spot $\mathrm{P} / \mathrm{C}$ ratio at a cut off value. 1.14 of $72 \%$ and $75 \%$, respectively. But they observed that the values of the spot urine P/C correlated well at higher levels of proteinuria. Thus, they concluded that the test could not rule out mild pre-eclampsia and hence should not be used to replace 24 hours urine protein estimation. Nischintha, Pallavee P, Ghose S et al, found a moderate correlation between 24 hours urine protein and spot urine $\mathrm{P} / \mathrm{C}$ ratio which was statistically significant $(\mathrm{r}=0.373, \mathrm{p}<0.001) .{ }^{10}$ The optimal cut-off value of spot urine $\mathrm{P} / \mathrm{C}$ ratio for significant proteinuria was $>0.6$ at which the sensitivity was $73.53 \%$ and specificity was $65.85 \%$.

\section{CONCLUSION}

By this study we concluded that protein: creatinine ratio in a random urine sample is better than random urine protein detection by dipstick method in cases of emergency when there is no time for detection of 24 hours urine protein.

- Sensitivity and specificity of 24 hours urine protein is best but this collection method is cumbersome and not possible in emergency, when there is no time.

- If cut-off level for urine protein: creatinine ratio in random urine sample is taken as 0.25 or more then sensitivity and specificity become same as 24 hours urine protein.

\section{Funding: No funding sources Conflict of interest: None declared}

Ethical approval: The study was approved by the Institutional Ethics Committee 


\section{REFERENCES}

1. Lindheimer MD, Conrad K, Karumanchi SA. Renal physiology and disease in pregnancy. In Alpern RJ, Hebert SC, (eds): Seldin and Giebisch's the kidney: Physiology and pathophysiology, $4^{\text {th }}$ ed. New York, Elsevier; 2008:2339.

2. Lindheimer MD, Taler SJ, Cunningham FG. Hypertension in pregnancy. J Am Soc Hyper. 2008;2(6):484-94.

3. Sibai BM, Stella CL. Diagnosis and management of atypical preeclampsia-eclampsia. Am J Obstet Gynecol. 2009;200(5):481-e1.

4. Papanna R, Mann LK, Kouides RW, Glantz JC. Protein/creatinine ratio in preeclampsia: a systematic review. Obstet Gynecol. 2008;112(1):135-44.

5. Dwyer BK, Gorman M, Carroll IR, Druzin M. Urinalysis vs urine protein-creatinine ratio to predict significant proteinuria in pregnancy. J Perinatol. 2008;28(7):461.

6. Shahbazian N, Hosseini AF: A comparison of spot urine protein- creatinine ratio with 24 hour urine protein excretion in women with pre-clampsia. Iranian J Kidney dis. 2008;2(3):127-31.

7. Hossain S, Ghosh A, Chatterjee A, Sarkar G, Mondal SS. To evaluate the diagnostic value of protein: creatinine ratio in a single voided urine sample for quantification of proteinuria compared to those of a 24-hour urine sample in patients with pre-eclampsia. J Col Med Sci Nepal. 2013;9(2):45-53.

8. Khan SM, Parven T, Zulfiquar S. A comparision of spot $\mathrm{P} / \mathrm{C}$ ratio vs $24 \mathrm{hr}$ urinary protein excretion in women with pre- eclampsia. Int J Obstet Gynaecol Res. 2014;2:67-72.

9. Aggarwal N, Suri V, Chopra V, Kohli HS. A prospective comparision of random protein/creatinine ratio vs $24 \mathrm{hr}$ urine protein in women with pre-eclampsia. Medscape J Med. 2008; 10:98.

10. Nischintha S, Pallavee $\mathrm{P}$, Ghose S. Correlation between 24-hour urine protein, spot urine protein/creatinine ratio, and serum uric acid and their association with fetomaternal outcomes in pre eclamptic women. J Natu Sci Biol Med. 2014;5(2):255.

Cite this article as: Sarkar R, Rawat S, Sharma NR, Tiwari HC. A study of spot urine protein: creatinine ratio as an alternative to 24 hours proteinuria for the diagnosis of pre-eclampsia. Int J Reprod Contracept Obstet Gynecol 2020;9:140-4. 